\title{
Acceptable Shelf Life of Indonesian Anti-Atherosclerosis Mixed Herbs Based on Bacterial Count and pH Stability
}

\author{
Dewi Tristantini $^{1 *}$, Berna Elya ${ }^{2}$, Sabila Robbani $^{1}$, Leon Lukhas Santoso $^{1}$ \\ ${ }^{1}$ Department of Chemical Engineering, Faculty of Engineering, Universitas Indonesia, Kampus UI Depok, \\ Depok 16424, Indonesia \\ ${ }^{2}$ Department of Pharmacy, Faculty of Pharmacy, Universitas Indonesia, Kampus UI Depok, Depok 16424, \\ Indonesia
}

\begin{abstract}
Anti-atherosclerosis herbs are extracted from a simplicia mixture of tanjung leaf (Mimusops elengi L.), starfruit leaf (Averrhoa carambola), and curcuma (Curcuma xanthorrhiza) by using water as a solvent. The contamination of microorganisms during the storage of these herbs should be considered as it can decrease the quality of the herbs and become poisoning food. The aim of this study was to examine the shelf life of anti-atherosclerosis herbs. The study tested the herbs for $\mathrm{pH}$ stability and bacterial count using the total plate count (pour plate) method by varying the temperature and duration storage for 48 hours. The results showed that the $\mathrm{pH}$ value of the antiatherosclerosis herbs was constant ( $\mathrm{pH}$ 5.7-5.6) for 48 hours in the refrigerator and 6 hours at room temperature. The bacterial count was $1.24 \times 10^{8} \mathrm{CFU} / \mathrm{ml}$ and $2.36 \times 10^{3} \mathrm{CFU} / \mathrm{ml}$ for 48 hours at room and refrigerator temperatures, respectively. Therefore, 48-hour refrigerator storage was an acceptable shelf life according to National Agency of Drug and Food Control (BPOM) Regulation Number 12 (2014) concerning the quality requirements of traditional medicine, which dictate that microorganisms in liquid herbs may not exceed $10^{4} \mathrm{CFU} / \mathrm{ml}$.
\end{abstract}

Keywords: Anti-atherosclerosis herb; pH testing; Shelf time; Total plate count

\section{Introduction}

Traditional medicine is consumed by many people because it is affordable, has few side effects, provides many benefits, and can even be made at home. According to Ekor (2014), the use of herbal products and supplements has increased tremendously over the past three decades, and no fewer than $80 \%$ of people worldwide rely on them for some part of their primary health care. Nevertheless, cases of poisoning caused by traditional medicine still exist. Based on data from the National Agency of Drug and Food Control (2016), as many as 65 cases of national poisoning were caused by traditional medicine in 2016 . Such poisoning indicates that the product should not be consumed any longer due to a change in quality, such as a chemical or physical change. One example of a physical change is discoloration (Rahayu and Hastuti, 2008), which occurs because of environmental conditions, such as temperature and microbial activity. Additionally, most herbal products are further compromised by a lack of suitable quality controls, inadequate labeling, and the absence of appropriate patient information (Ekor, 2014). 
One of the factors affecting the quality of traditional medicine products is how the consumers store, distribute, and use the product; this affects food safety and shelf life. The Food Safety Authority of Ireland (FSAI, 2017) explained that temperature is an important factor in the reasonably controllable conditions of storage, distribution, and use. In many circumstances, food will experience temperature variation. Therefore, when determining and validating shelf life, which temperature or temperatures are appropriate for the food must be carefully considered. Producers must base their predictions for appropriate temperatures on the storage system, whereas wholesalers and retailers should use printed shelf-life data to reduce unnecessary waste (Göransson et al., 2018).

Generally, Indonesian societies are still not aware of the importance of health. People in these societies tend to have an unhealthy lifestyle and pay little attention to the food they consume daily. Due to these lifestyle factors, heart disease and atherosclerosis have become major causes of morbidity in Indonesia over the last decade. Atherosclerosis is a condition in which narrowing and hardening of the arteries occur due to deposits of cholesterol, protein, and minerals in metabolic waste (Campbell et al., 2008).

One traditional medicine whose storage methods should be considered is antiatherosclerosis herbs. These herbs are a simplicia mixture of tanjung leaves (Mimusops elengi L.), starfruit leaves (Averrhoa carambola), and curcuma (Curcuma xanthorriza). In Central Java, a combination of these three herbs has been empirically shown to be an effective herbal medicine for blood clots and blood circulation (Rahminiwati et al., 2019). The anti-cholesterol effect of tanjung leaves has already been tested pre-clinically, and most of the catechins in the leaves' extract are 36\% effective for decreasing cholesterol levels in mice (Tristantini and Pradana, 2017). Starfruit leaves have also been tested by Shahreen et al. (2012), who found that their extract has antihyperglycemic properties. To reduce atherosclerosis in blood vessels, cholesterol levels can be reduced naturally by optimizing liver metabolism. Thus, curcuma is hepatoprotective and can optimize liver metabolism due to its flavonoids protect liver cells from toxic substances, of which curcuminoid is the most common (Devaraj et al., 2010). The functional correlation between anti-cholesterol, anti-hyperglycemic, and hepatoprotection for increasing anti-atherosclerosis ability of these materials is shown in Figure 1. Due to the individual properties of each ingredient, a combination of $8.50 \mathrm{~g}$ of tanjung leaves, $2.55 \mathrm{~g}$ of starfruit leaves, and $13 \mathrm{~g}$ of curcuma in $600 \mathrm{ml}$ of water is an anti-atherosclerosis herb with anti-cholesterol activity (Tristantini and Christina, 2018). According to Tristantini and Amelinda (2018), the extract has satisfactory anti-atherosclerosis properties with hypotensive activity in mice.

Although the raw material storage life estimation of anti-atherosclerosis mixed herbs has already been tested and has met the standards of the National Agency of Drug and Food Control (BPOM), the shelf life of the extract must also be studied (determining the shelf life of traditional medicines is mandatory based on government regulations (Tristantini et al., 2019). According to Mulia et al. (2015), the stability of a product needs to be maintained during the extraction of bioactive compounds, as this stability will affect the function of the compound. After determining the optimal tolerances, final product design selection can be conducted along with production allocation to the selected process (Rosyidi et al., 2016). Therefore, this study aimed to determine the shelf life of the anti-atherosclerosis herbs to maintain the quality and prevent people from being poisoned. 


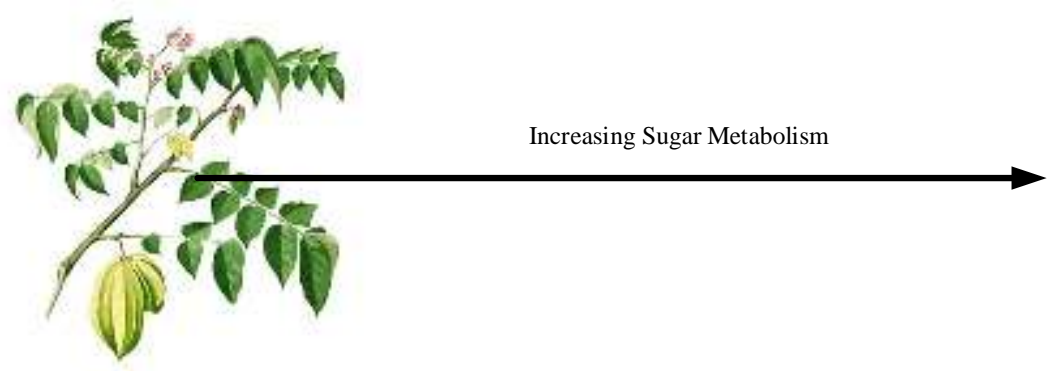

Averrhoa carambola
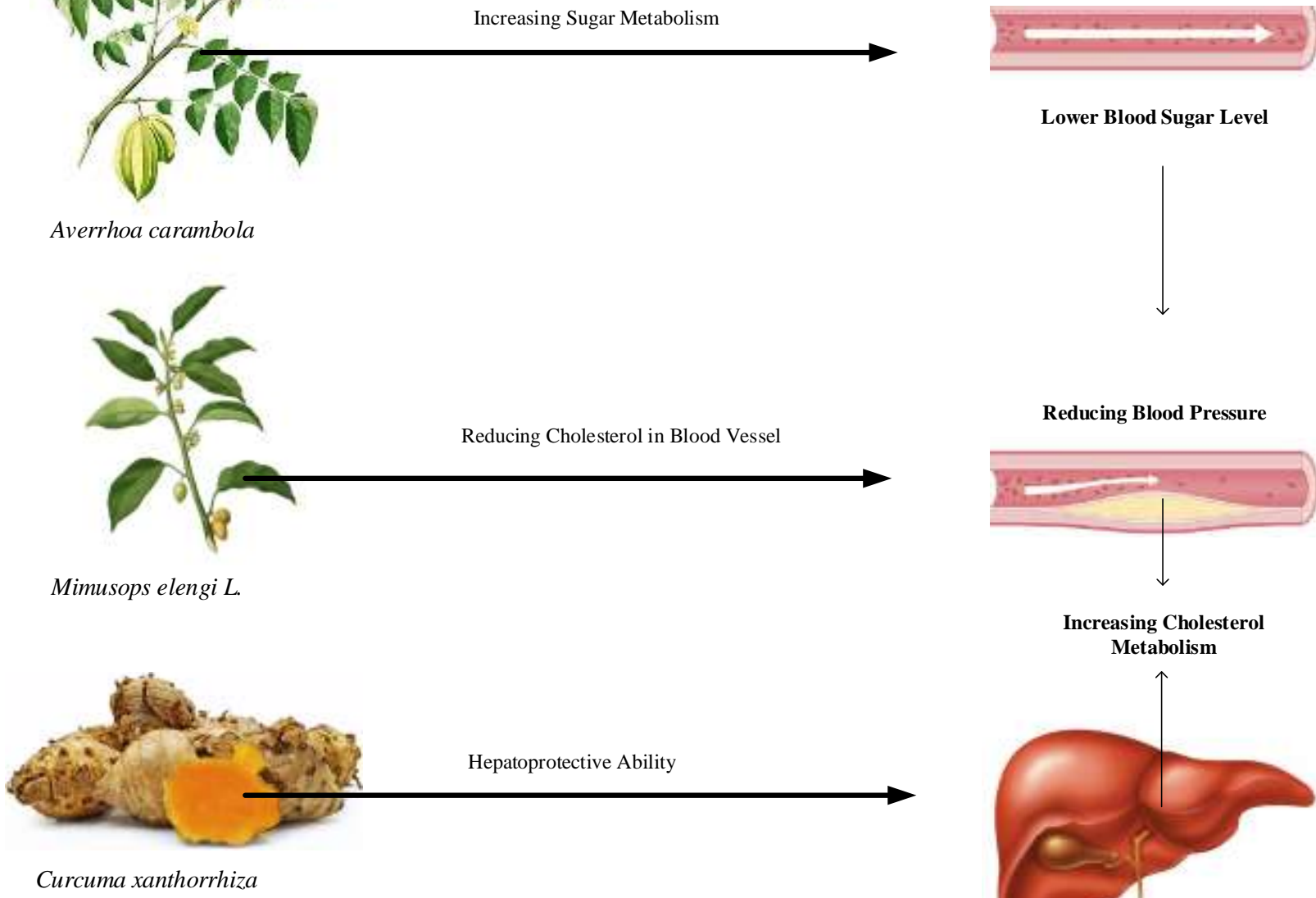

Reducing Blood Pressure

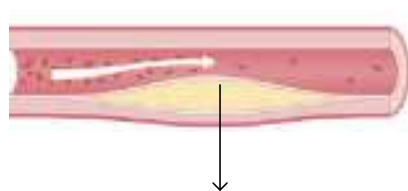

Increasing Cholesterol Metabolism

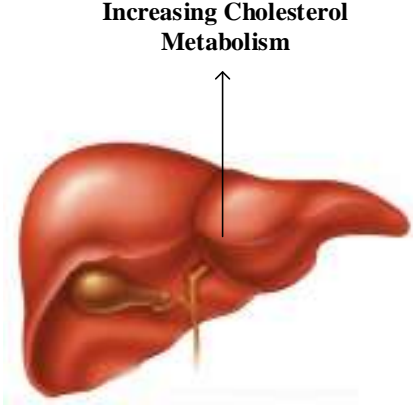

Figure 1 The functions of the ingredients of Indonesian anti-atherosclerosis mixed herbs

\section{Methods}

\subsection{Preparation of Simplicia}

The tanjung and starfruit leaves were washed with tap water. Before washing with tap water, the skin of the curcuma was peeled. After it was washed, it was cut into slices. The materials were dried in sunlight for 1 week and then continued to dry in an oven at a temperature of $60^{\circ} \mathrm{C}$ for 1 hour. Then, all materials were crushed with a blender and mixed to create a $60<\mathrm{D}<16$ mesh size.

\subsection{Preparation of Plant Extract}

Using $300 \mathrm{ml}$ water as a solvent, $12 \mathrm{~g}$ of dried, ground samples were extracted. Reflux extraction was performed for 45 minutes at $80-85^{\circ} \mathrm{C}$. The extracts were filtered and then evaporated using a rotary evaporator until they were at half their initial volume.

\section{3. $p H$ Stability Test Method}

The extracted herbs were stored in a small airtight bottle. The storage area was divided into two conditions: refrigerator temperature $\left(0-5^{\circ} \mathrm{C}\right)$ and room temperature $\left(25-27^{\circ} \mathrm{C}\right)$. The herbs were stored for 48 hours, and the pH stability of $10 \mathrm{ml}$ of the herbs was tested every 6 hours using $\mathrm{pH}$ meters.

\subsection{Total Plate Count}

The pour plate method was used to calculate the number of bacteria in the herbs. The extracted herbs were stored at room and refrigerator temperatures, respectively, for 48 
hours. Every 24 hours, $1 \mathrm{ml}$ of the samples from the room and refrigerator was taken and placed in $9 \mathrm{ml} \mathrm{NaCl} 0.9 \%$ to make a $10^{-1}$ dilution. This same step was performed until a $10^{-7}$ dilution was reached. Then, $1 \mathrm{ml}$ of each dilution was placed in a sterile petri dish. To the petri dish, $20 \mathrm{ml}$ of sterile Tryptic Soy Agar medium at $45-50^{\circ} \mathrm{C}$ was added, mixed, and solidified with the samples. After mixing, the samples were incubated at $22-25^{\circ} \mathrm{C}$ for $24-$ 48 hours. Then, the colonies of bacteria were calculated.

The total plate count was calculated using Equation 1 from Bacteriological Analytical Manual (BAM) to determine number of colonies (Maturin and Peeler, 2001), and the results were expressed as $\mathrm{CFU} / \mathrm{ml}$.

$$
N=\frac{\sum C}{\left[\left(1 \times n_{1}\right)+\left(0.1 \times n_{2}\right) x(d)\right]}
$$

where $N$ is the number of colonies per ml or g of product, $\sum C$ is the sum of all colonies on all plates counted, $n_{1}$ is the number of plates counted in the first dilution, $n_{2}$ is the number of plates counted in the second dilution, and $d$ is the dilution from which the first counts were obtained.

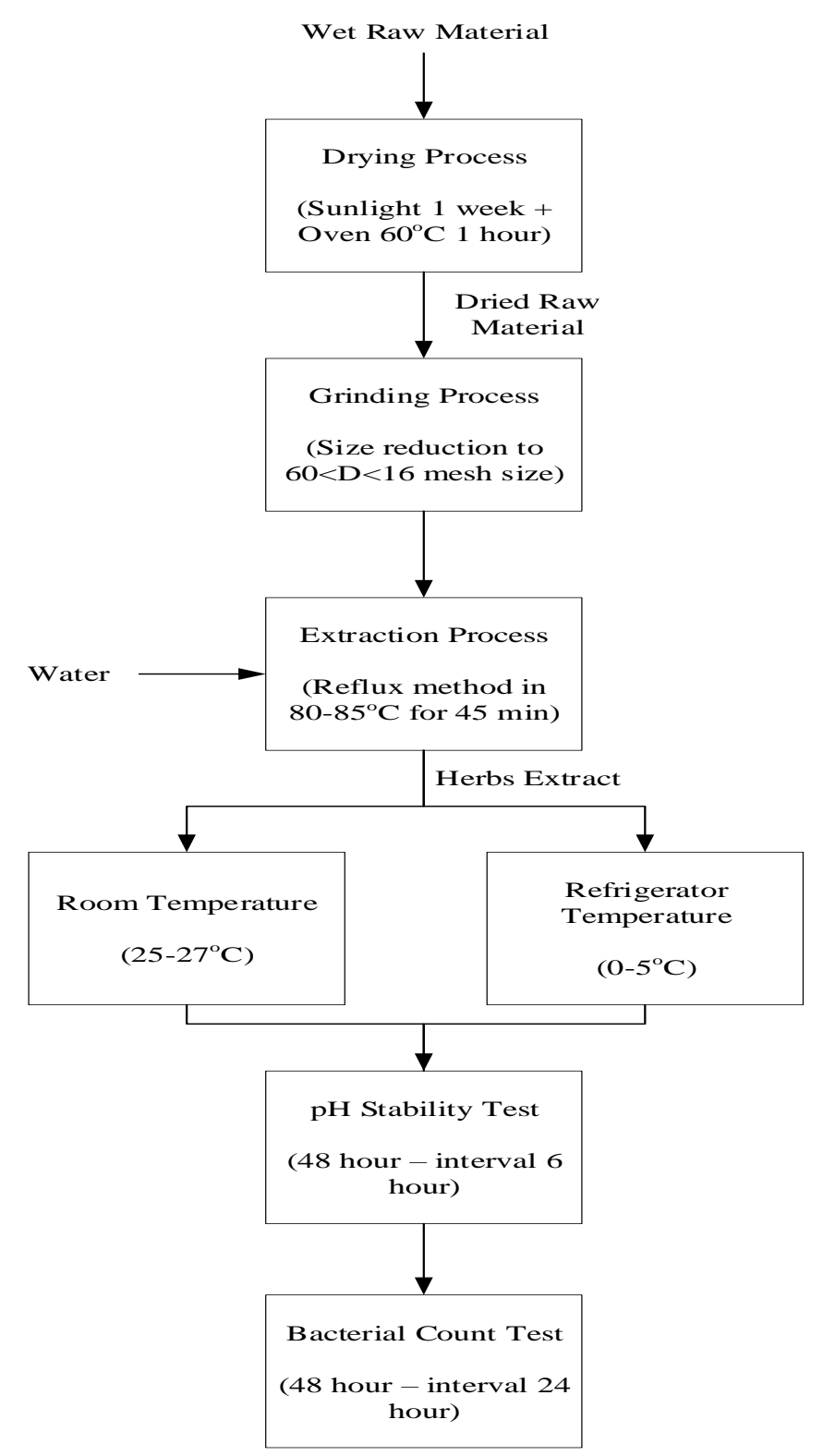

Figure 2 Block flow diagram of the process 


\section{Results and Discussion}

\section{1. $p H$ Stability}

According to Rienoviar and Nashrianto (2010), pH stability is related to the distribution of uniform raw materials and the quality of herbal products. For example, products that have high acidity or low $\mathrm{pH}$ are more durable because microbes will have difficulty growing in acidic media. Additionally, significant changes in a product's $\mathrm{pH}$ may affect the taste of the product which can reduce the overall quality. The pH stability of the anti-atherosclerosis herbs is shown in Figure 3.

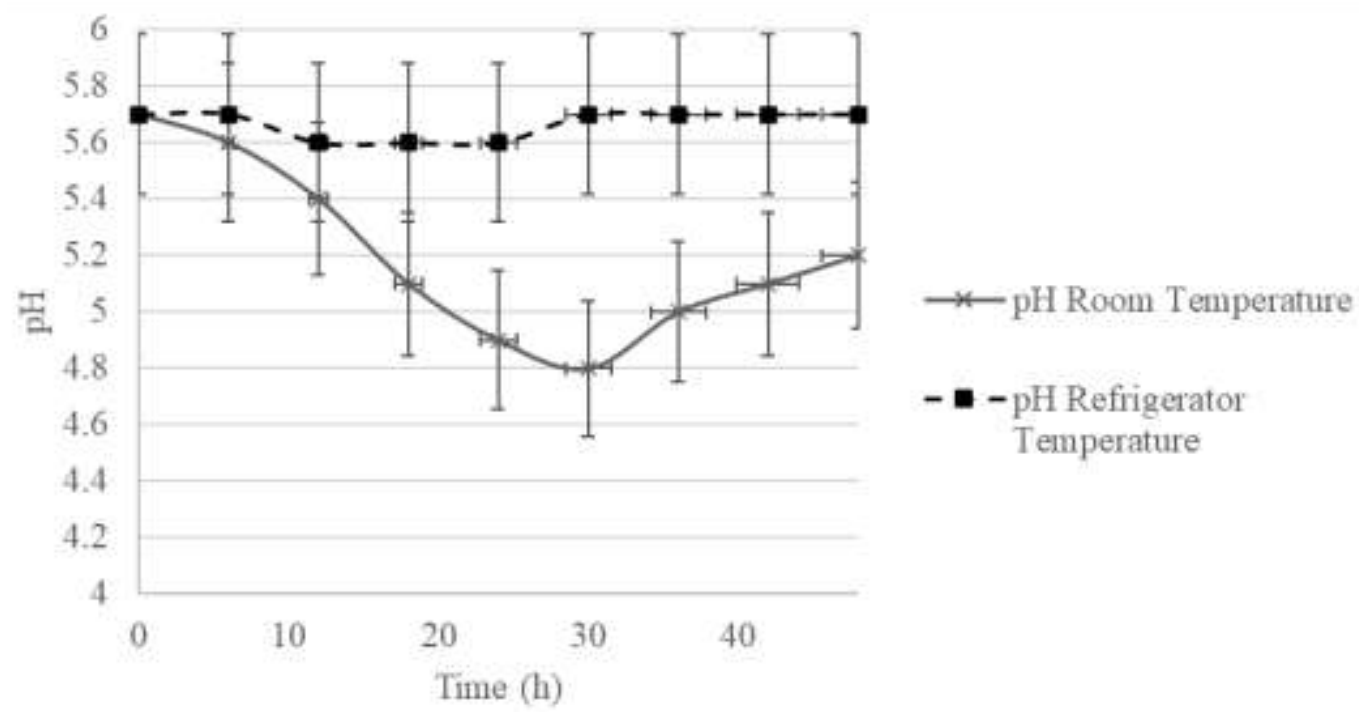

Figure 3 Effect of various storage times and temperatures on pH stability

Initially, the herbs had a $\mathrm{pH}$ of 5.7. The $\mathrm{pH}$ decreased gradually in the room samples, while it was constant in the refrigerator samples during the 48 hours of storage. These changes in $\mathrm{pH}$ indicated bacterial growth activity because the initial $\mathrm{pH}$ of the herb was in the optimal range for bacteria growth (5-8.5). Additionally, the decrease in $\mathrm{pH}$ was due to the degradation of polyphenolic compounds in the herb which is caused by food bacteria (Mtewa, 2017), a process that is affected by temperature, oxygen content, and light (Vatai et al., 2009). Indeed, the high amount of oxygen content in the water solvent can lead to oxidation of the active substance (Rahayu and Hastuti, 2008). The varied pH in room temperature storage may have been due to non-homogeneous stirring (Rienoviar and Nashrianto, 2010).

Several studies have shown the relationship between $\mathrm{pH}$ and storage conditions. Mtewa (2017) conducted a study of the storage of Malawian herbal formulations in water in various containers for 10 days and showed that the storage container did not affect the $\mathrm{pH}$ value. However, the $\mathrm{pH}$ decreased continually during the 10 days, from 6.2 to 4 . This indicated that storage duration affects pH. Furthermore, Martinus (2014) performed a pH stability study on aquamarine extracts in water to determine whether the stability was affected by storage duration and temperature. The extract was stored at room temperature $\left(25^{\circ} \mathrm{C}\right)$ and at a cold temperature $\left(5^{\circ} \mathrm{C}\right)$ for 24 hours. The results were similar to those found by the present study concerning the anti-atherosclerosis herbs; at room temperature, $\mathrm{pH}$ decreased from 6.1 to 6 within 12 hours and continued to decrease to 5.83 within 24 hours. Storage at cold temperatures also caused a decrease in $\mathrm{pH}$, but the decrease was not significant (to 6 within 24 hours). Similarly, the present study showed that storage at a certain temperature and for a certain amount of time can affect the acidity of anti- 
atherosclerosis herbs, which indicates the quality of the herb.

\subsection{Bacterial Count}

According to Sanders (2012), the pour plate method can be used to count the number of microorganisms in a mixed sample by adding the sample to a molten agar medium before its solidification. This process uniformly distributes the colonies throughout the solid medium when the appropriate sample dilution is plated. Additionally, the colonies form within as well as on the surface of the agar medium, thus providing a convenient means to count the number of viable cells in a sample.

The factors of bacterial growth were divided into three categories according to the Busta et al. (2003) and the FSAI (2017): intrinsic factors, extrinsic factors, and other factors. Intrinsic factors included moisture content/water activity, $\mathrm{pH}$ and acidity, nutrient content, biological structure, redox potential, antimicrobial ability, and competitive microflora. Extrinsic factors included the type of packaging/atmosphere, the effect of time/temperature, storage conditions, relative humidity, and processing steps. Other factors included the intended end-use of the product, the product history, and the factors' interaction. Additionally, predictable changes occur in herbal medicinal products during storage and shelf life, including bacterial reaction such as hydrolysis and oxidation which causing racemization, geometric isomerization, temperature, moisture, and light (Sachan and Kumar, 2015). Based on the results of the bacterial counts (Table 1), the possible factors of bacterial growth in the anti-atherosclerosis herbs were temperature, $\mathrm{pH}$, moisture/water content (which was related to hydrolysis), and nutrient content.

Table 1 Bacterial count based on time and temperature

\begin{tabular}{ccc}
\hline \multirow{2}{*}{$\begin{array}{c}\text { Time } \\
\text { (h) }\end{array}$} & \multicolumn{2}{c}{ Bacterial Count (CFU/ml) } \\
\cline { 2 - 3 } & $\begin{array}{c}\text { Room } \\
\text { Temperature }\end{array}$ & $\begin{array}{c}\text { Refrigerator } \\
\text { Temperature }\end{array}$ \\
\hline 0 & & $5.8 \times 10^{3}$ \\
\hline 24 & $2.63 \times 10^{7}$ & $7.2 \times 10^{3}$ \\
\hline 48 & $1.24 \times 10^{8}$ & $2.36 \times 10^{3}$ \\
\hline
\end{tabular}

The first factor of bacterial growth was temperature. As seen in Table 1, the number of bacteria increased significantly from the initial hour at room temperature, which was in the optimal temperature range for bacterial growth $20-45^{\circ} \mathrm{C}$ (FSAI, 2017; Busta et al., 2003). Furthermore, structural cell components become denatured, and heat-sensitive enzymes are deactivated at high energy accumulation (Busta et al., 2003). Therefore, although the growth rate increases with increasing storage time, the rate tends to decline rapidly as the energy has accumulated high enough from bacterial reaction. In the refrigerator samples, the bacteria growth did not differ significantly from the initial hour because the low temperature slowed the reaction rates for the individual enzymes in the organism and reduced the fluidity of the cytoplasmic membrane, thereby interfering with the transport mechanism. With the reaction rates slowed down, the bacteria couldn't reproduce because of the lack of energy accumulation.

The second factor of bacterial growth was the moisture content/water activity. The ratio of simplicia to water in this study was $1: 25$, which was not ideal (the ideal solvent to sample ratio is 10:1 v/w; (Tiwari et al., 2011). According to Desrosier (2010), water is one of the primary sources of bacteria growth, as it provides an oxygen source for respiration, supports chemical metabolic reactions, and maintains osmotic pressure. Thus, the water 
content or water activity in the product can affect its shelf life due to the growth of microorganisms; higher water content leads more quickly to damage because of microorganism activity (Rahayu and Hastuti, 2008). Moreover, Sachan and Kumar (2015) showed that higher water content leads to hydrolysis, a reaction that results in the product's degradation.

Another factor of bacterial growth was the nutrients in the product. Microorganisms require certain basic nutrients to grow and maintain metabolic functions, including water, a source of energy, nitrogen, vitamins, and minerals (Busta et al., 2003). The abundance of nutrients in most foods is sufficient to support the growth of a wide range of foodborne pathogens. Most microorganisms will metabolize simple sugars such as glucose, but others can metabolize more complex carbohydrates, such as starch or cellulose found in plant foods. Additionally, some microorganisms can use fats as an energy source. Furthermore, amino acids serve as a source of nitrogen and energy and are utilized by most microorganisms. Other sources of nitrogen include urea, ammonia, creatinine, and methylamines. The minerals required for microbial growth include phosphorus, iron, magnesium, sulfur, manganese, calcium, and potassium. Therefore, the rate of growth is limited by the availability of these essential nutrients.

Each material in the anti-atherosclerosis herb mixture contained the essential nutrients (Tristantini and Amalia, 2019). For example, curcuma contains polyphenol such as curcuminoid (Rosidi et al., 2016). The ethanolic extract of $M$. elengi leaves contains quercitol, hentriacontane, and $\beta$-carotene (Singh et al., 2014). The extract of starfruit's leaves contains flavonoids compound such as terpenoids, tannins, glycosides, and alkaloids (Mewara et al., 2017). These contents reduced bacterial growth as bioactive and polyphenolic compounds can damage cell wall structures (i.e., an antibacterial activity; Sahlan et al., 2018; Bora et al., 2020).

\subsection{Regulation Acceptability Analysis}

According to regulations of the Indonesian National Standardization Agency, the extract cannot be kept too long in storage, as the bacterial reaction could make food acidity at pH of 3.5-4 (Martoyo et al., 2014). Therefore, Indonesian anti-atherosclerosis mixed herbs must be consumed as soon as possible after extraction. To produce this mixture on a mass level, preservation of the extract that is compliant with food and pharmaceutical preservative regulations must be determined.

According to regulation number 12 of the National Agency of Drug and Food Control (2014) concerning the quality requirements for traditional medicine, the total plate count of microbial contamination in medicinal liquid may not exceed or equal $10^{4} \mathrm{CFU} / \mathrm{ml}$. Moreover, one of the six principles of food hygiene and sanitation from the Ministry of Health of the Republic of Indonesia (2000) states that cooked food should be stored at a low temperature so the growth of microorganisms that could damage the food can be resisted. Therefore, this study found that the herb was still safe to be consumed after storage at refrigerator temperatures for up to 48 hours.

\section{Conclusions}

Based on $\mathrm{pH}$ testing on anti-atherosclerosis herbs, samples stored in the refrigerator for 48 hours had a more constant $\mathrm{pH}$ than those stored at room temperature for 12 hours. Based on the bacterial count of the anti-atherosclerosis herbs after 48 hours, herb storage at room temperature produced a higher number of colonies $\left(1.24 \times 10^{8} \mathrm{CFU} / \mathrm{ml}\right)$ than storage in the refrigerator $\left(2.36 \times 10^{3} \mathrm{CFU} / \mathrm{ml}\right)$. The factors determining bacterial growth were $\mathrm{pH}$, temperature, water, and nutrient content. According to National Agency of Drug 
and Food Control (BPOM) regulations, herb storage in the refrigerator for 48 hours is safe. Therefore, anti-atherosclerosis herbs extract has the potential for safe shelf life right after extraction process based on these results.

\section{Acknowledgements}

The authors thank the research, lecturer, and academic staff in the Department of Chemical Engineering, Universitas Indonesia, for providing the necessary facilities to carry out this study. This research was partially funded by the Publikasi Terindeks Internasional Saintekes (PUTI-Saintekes - Contract Number. NKB-2438/UN2.RST/HKP.05.00/2020), Massachusetts Institute of Technology-Indonesia Research Alliance (MIRA) Program, and World Class University (WCU) Program, which is managed by the Directorate of Research and Community Service Universitas Indonesia, Institut Teknologi Bandung and the Research Center for Biomedical Engineering, Universitas Indonesia, respectively.

\section{References}

Bora, H., Kamle, M., Mahato, D.K., Tiwari, P., Kumar, P., 2020. Citrus Essential Oils (CEOs) and their Applications in Food: An Overview. Plants, Volume 9(3), pp. 1-25

Busta, F.F., Bernard, D.T., Gravani, R.B., Hall, P., Pierson, M.D., Prince, G., Schaffner, D., Swanson, K.M., Woodward, B., Yiannas, F., 2003. Evaluation and Definition of Potentially Hazardous Foods. Comprehensive Reviews in Food Science and Food Safety, Volume 2(2), pp. 8-14

Campbell, N., Reece, J., Urry. L., Cain, M., Wasserman, S.A., Minorsky, P., Jackson, R., 2008. Biology. $8^{\text {th }}$ Edition. USA: Pearson Benjamin Cummings

Desrosier, N.W., 2010. The Technology of Food Preservation. $3^{\text {rd }}$ Edition. Indonesia: Universitas Indonesia Press

Devaraj, S., Esfahani, A.S., Ismail, S., Ramanathan, S., Yam, M.F., 2010. Evaluation of the Antinociceptive Activity and Acute Oral Toxicity of Standardized Ethanolic Extract of the Rhizome of Curcuma xanthorrhiza Roxb. Molecules, Volume 15(4), pp. 2925-2934

Ekor, M., 2014. The Growing Use of Herbal Medicines: Issues Relating to Adverse Reactions and Challenges in Monitoring Safety. Frontiers in Pharmacology, Volume 4(177), pp. 110

Food Safety Authority of Ireland (FSAI), 2017. Guidance Note No. 18: Validation of Product Shelf-Life Rev. 3, Office of Food Safety Authority of Ireland, Dublin, Ireland

Göransson, M., Nilsson, F., Jevinger, Å., 2018. Temperature Performance and Food Shelf-Life Accuracy in Cold Food Supply Chains: Insights from Multiple Field Studies. Food Control, Volume 86, pp. 332-341

Rahayu, I.D., Hastuti, S.D., 2008. Stabilitas Saponin sebagai Antibiotik Alami Hasil Isolasi Gel Daun Aloe barbadensis miller pada Variasi Suhu dan Lama Simpan (The Stability of Saponin as Natural Antibiotic that is Isolated from Aloe Barbadensis Miller Leaf in Different Temperature and Storage Duration). Journal Protein, Volume 15(1), pp. 60-68

Martinus, 2014. An Activity Test of Butterfly Pea (Clitoria ternatea L.) Extract in Water to Decay Cortical Cataract. Undergraduate Thesis, Department of Chemical Engineering, Faculty of Engineering, Universitas Indonesia, Depok, West Java, Indonesia

Martoyo, P.Y., Hariyadi, R.D., Rahayu, W.P., 2014. Kajian Standar Cemaran Mikroba dalam Pangan di Indonesia (Bacterial Count Standard in Indonesian Food and Beverages). Jurnal Standardisasi, Volume 16(2), pp. 113-124

Maturin, L., Peeler, J.T., 2001. BAM Aerobic Plate Count. Bacteriological Analytical Manual. US Food and Drug Administration, New Hampshire Avenue Silver Spring USA 
Mewara, D., Tamakuwala, H., Desai, B., 2017. Antifungal Activity and Phytochemical Screening from Leaf Extract of Manilkara zapota and Averrhoa carambola. BMR Phytomedicine, Volume 3(1), pp. 1-9

Ministry of Health of the Republic of Indonesia, 2000. Principle of Food Hygiene and Sanitation. Office of Ministry of Health of the Republic of Indonesia, Jakarta, Indonesia

Mulia, K., Krisanti, E., Terahadi, F., Putri, S., 2015. Selected Natural Deep Eutectic Solvents for the Extraction of $\alpha$-Mangostin from Mangosteen (Garcinia mangostana L.) Pericarpp. International Journal of Technology, Volume 6(7), pp. 1211-1220

Mtewa, A., 2017. Antibacterial Potency Stability, pH, and Phytochemistry of Some Malawian Ready-To-Use Aqueous Herbal Formulations Used Against Enteric Diseases. International Journal of Herbal Medicine, Volume 5(3), pp. 1-5

National Agency of Drug and Food Control, 2014. Head Regulation of BPOM RI No. 12 about Quality Requirements of Traditional Medicine. Office of National Agency of Drug and Food Control, Jakarta, Indonesia

National Agency of Drug and Food Control (BPOM), 2016. National Toxicity Information Center. Office of National Agency of Drug and Food Control, Jakarta, Indonesia. Available Online at http://ik.pom.go.id/v2016, Accessed on 5 May 2017

Rahminiwati, M., Safitri, W., Noviana, D., 2019. Curcuma, Tanjung leaves, and Sweet Starfruit Leaves Mixed Herbs for Antiarrythmia Testing to Cat with Potential Electrodiogram. Jurnal Veteriner, Volume 20(3), pp. 409-417

Rienoviar, N.H., Nashrianto, H., 2010. Penggunaan Asam Askorbat (Vitamin C) untuk Meningkatkan Daya Simpan Sirup Rosela (Hibiscus sabdariffa Linn.) (The Utilization of Ascorbic Acid on Enhancement Endurance Time of Roselle Syrup (Hibiscus sabdariffa Linn.)). Jurnal Hasil Penelitian Industri, Volume 23(1), pp. 8-18

Rosidi, A., Khomsan, A., Setiawan, B., Riyadi, H., Briawan, D., 2016. Antioxidant Potential of Temulawak (Curcuma xanthorriza Roxb.). Pakistan Journal of Nutrition, Volume 15(6), pp. 556-560

Rosyidi, C.N., Fatmawati, A., Jauhari, W.A., 2016. An Integrated Optimization Model for Product Design and Production Allocation in a Make to Order Manufacturing System. International Journal of Technology, Volume 7(5), pp. 819-830

Sachan, A.K., Kumar, A., 2015. Stability Testing of Herbal Products. Journal of Chemical and Pharmaceutical Research, Volume 7(12), pp. 511-514

Sahlan, M., Damayanti, V., Tristantini, D., Hermansyah, H., Wijanarko, A., Olivia, Y., 2018. Antimicrobial Activities of Pomelo (Citrus maxima) Seed and Pulp Ethanolic Extract. In: AIP Conference Proceedings (Volume 1933(1), p. 030002). AIP Publishing LLC

Sanders, E.R., 2012. Aseptic Laboratory Techniques: Plating Methods. Journal of Visualized Experiments, Volume 63, pp. 1-18

Shahreen, S., Banik, J., Hafiz, A., Rahman, S., Zaman, A.T., Shoyeb, A., Chowdhury, M.H., Rahmattullah, M., 2012. Antihyperglycemic Activities of Leaves of Three Edible Fruit Plants (Averrhoa carambola, Ficus Hispida, and Syzgium samarangense) of Bangladesh. Journal of Traditional Complement and Alternative Medicine, Volume 9(2), pp. 287-291

Singh, K.L., Srivastava, P., Kumar, S., Singh, D.K., Singh, V.K., 2014. Mimusops elengi Linn. (Maulsari): A Potential Medicinal Plant. Archives of Biomedical Sciences, Volume 2(1), pp. 18-29

Tiwari, P., Kumar, B., Kaur, M., Kaur, G., Kaur, H., 2011. Phytochemical Screening and Extraction: A Review. Internationale Pharmaceutica Sciencia, Volume 1(1), pp. 98-106

Tristantini, D., Amalia, R., 2019. Quercetin Concentration and Total Flavonoid Content of Anti-atherosclerotic Herbs using Aluminum Chloride Colorimetric Assay. In: AIP Conference Proceedings (Vol. 2193, No. 1, p. 030012). AIP Publishing LLC 
Tristantini, D., Amelinda, K., 2018. Hypotensive Effect of Aqueous Extract of Jamu Antiatherosclerosis in Male Rats. In: AIP Conference Proceedings (Volume 1933(1), p. 030012). AIP Publishing LLC

Tristantini, D., Christina, D., 2018. Anti-cholesterol Activity in Vivo Test of Multifunction Herbs Extract in the Water using in Vivo Method in Mice (Mus musculus L.) DDY-strain. In: AIP Conference Proceedings (Vol. 1933(1) p. 030003). AIP Publishing LLC

Tristantini, D., Pradana, B.T., 2017. Anti-cholesterol Activity Test of Tanjung (Mimusops elengi L.) Leaf Extract in the Water using in Vivo Method in Mice (Mus musculus L.) DDY-strain. In: AIP Conference Proceedings (Volume 1817(1), p. 030009). AIP Publishing LLC

Tristantini, D., Ramadhan, M.R., Hanifah, A., 2019. Shelf Life Estimation of Antiatherosclerosis Herbs using ASLT: Critical Water Content and Sorption Isotherms Model. In: AIP Conference Proceedings, Volume 2193(1), p. 030013,. AIP Publishing LLC

Vatai, T., Kerget, M., Knez, Z., 2009. Extraction of Phenolic Compounds from Elder Berry and Different Grape Marc Varieties using Organic Solvents and/or Supercritical Carbon Dioxide. Journal of Food Engineering, Volume 90(2), pp. 246-254 